\title{
The use of oikovopía for the missional plan and purpose of God in Ephesians 1:3-14
}

\section{Timothy van Aarde ${ }^{1}$}

\begin{abstract}
The term oikovouía is used in the Pauline epistles with a specific nuance. It is Paul who uses it specifically as a missional term. He uses oikovouía in Ephesians for the missions activity of God, the missio Dei (Eph 1:10), his own mission activity and the proclamation of the gospel (Eph 3:2) and for the missions activity of the church. The mission of the church is discernible through a missional hermeneutic and reading of Ephesians and the identification of the missional calling of the church.

In this paper it is my contention that oikovopí $\alpha$ is an important term in a missional reading of the epistle to the Ephesians. This paper will focus on the importance of the word oikovouí $\alpha$ for missions in Ephesians. The use of oikovouí $\alpha$ as a missional term in the epistle to the Ephesians will support the proposal that oikovouí $\alpha$ is to be read as a missional term in all of its occurrences in the Pauline Epistles. The contention of this article is that a missional hermeneutic should be employed when we read the Pauline epistles ${ }^{2}$ because Paul's mission undergirds and shaped the text. This article will serve as an introduction to a series of articles in which the purpose of the letter to the Ephesians will be revisited.
\end{abstract}

\section{Introduction: The term oik ovouí $\alpha$ and equivalent for the missio Dei}

David Bosch employed a missional hermeneutic in the reading of Luke (cf. Bosch 1991:88, 104). It was a bold and controversial claim within biblical studies. It led to insights and steps taken toward a missional reading of Matthew and Paul. The insights of Bosch have led to the development of a missional hermeneutic that has continued to move forward toward a more consistent expression of the centrality of mission in Scripture (cf. Goheen 2005:254). The article indicates that in a missional reading of Ephesians that the missio Dei is a central concept in such a reading ${ }^{3}$.

1 Dr. Timothy van Aarde is a researcher for the Department of Humanities, North West University.

2 The Pauline authorship of Ephesians has been questioned. The author of the Ephesian epistle acknowledges the role Paul played in the missions movement of the gospel in the letter itself, "I Paul the prisoner of Christ" (Eph 3:1, 7) and the making known of the mystery to the Gentiles (Eph 3:2-7). The demonstration of the significance of Ephesians for missions is not dependent upon establishing who the actual author may have been, Paul or someone else. This also applies to the rest of the Pauline corpus.

3 The missional task of the church cannot be carried out when the term missio Dei is used in a general sense (Breed 2014:8). 
In Ephesians ecclesiology and missiology are inseparably linked and bound together so that to be church is to be missional ${ }^{4}$. "The church was made for mission - God's mission" (Wright 2004:133). Jesus Christ is presented as present in the church and through the church in the world through "the missional ecclesiology of Ephesians" (Van Engen 1996:105). The term missional ecclesiology is used for the missionary nature of the local congregation. In Ephesians the missionary nature of the church is expounded through the missional ecclesiology of the letter. The article proposes that in the relationship of church and mission the term oikovouía occupies a prominent role, "the focal point" (Lincoln 1990:33)5. It appears three time in Ephesians (1:10; 3:2 \& 3:9) of the times Paul uses it and its derivatives (Col 1:25; 1 Co 4:1, 9:17; 1 Tim 1:4; Tit 1:7; 1 Pet 4:10) ${ }^{6}$. The relevance of this article is that in a postmodern world in which the church is being increasingly marginalized and consequently in an identity crises, a common response is to withdraw from missional involvement in the postmodern world ${ }^{7}$. A missional reading of Ephesians challenges the church to have a missional involvement in the world.

\section{The use of oikovopía in the eschatological framework of Paul}

The plan of God for the future is revealed in the letter to the Ephesians (cf. Floor 2011:469). Paul sets the concept of oikovouí in the context of the eschatological idea of two ages which brings a dynamic tension between two ages, the present and the future age, as part of God's plan. The future aeon has already begun although with it the aeon of this world has not yet ended so that there is a tension between the two ages. Paul's concept of mission takes place in a time of the eschatological overlap of the ages with two horizons, the divine restoration of creation by the Spirit and simultaneously the continuation of corruption, evil and lawlessness until the consummation. Mission exists because of the eschatological tension of the ages, until the kingdoms of the earth become the kingdom of God and mission ceases

4 The "body of Christ" image is used in a context which relates Christ to the world and the church in Ephesians 1:19-23, connecting ecclesiology and missiology. The church is passively and actively involved in the mystery being made known to the rulers and authorities in the heavenlies (cf. Eph 3:9-10). The term mystery is applied to the church consisting of Jew and Gentile which was previously hidden but now has been revealed (Eph 3:3-6). The revelation of the mystery of the gospel (Eph 3:2) is part of the task given to Paul. Ecclesiology and missiology are thus related through the use of the mystery. The church as being missional in its very nature links ecclesiology and missiology.

5 "It is both legitimate and illuminating to place the thought of 1:10 in the context of the whole letter" (Lincoln 1990:33).

6 In the examination of the term $\mu$ as a missional concept it is sufficient to recognize that this concept was either used by Paul or attributed to him and the argument of Pauline authorship does not directly influence the use of the term by Paul or others.

7 A challenge exists for evangelism and missions in the West because of prevailing postmodern attitudes (cf. Wright \& Lamb 2009:79). 
to exist. "Paul makes it plain that his special missionary activity is part of a larger whole" (0'Brien 1993:54). It was set within the eschatological framework of the present and the future.

\subsection{The Trinitarian framework and the missio Dei}

A harmonious relationship with each of the three persons of the Trinity is worked out through the oikovoui $\alpha$ ministry of Christ. It is through restored relationship with God in Trinity that members of the church are able to serve one another and the world in the service of the missio Dei. Mission has its origins in the Trinitarian being and action of God (cf. Van Engen 1996:151). For this reason the doctrine of the Trinity is the starting point of our missionary work (cf. Newbigin 1963:33). The concept of oikovoui $\alpha$ is a central part of the Trinitarian structure of Ephesians 1:3-14. The term is missional as it is grounded in the work of the Trinity, God the Father takes the initiative, Jesus Christ implements the plan and purposes of the

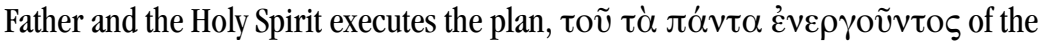
Father. The roles of the person of the trinity are, "The Father electing (vv. 4-6), the Son saving (w. 7-12) and the Spirit sealing (w. 13-14), each stanza ending with the catchphrase "to the praise of his glory" (w. 6, 12, 14) (Grizzle 2013:31). "It is because of the Father's selecting (wv. 4-6), the Son's sacrifice (w. 7-12), and the Spirit's sealing (w. 7-12) that believers are blessed" (Grizzle 2013:31). It is from the inner dynamic movement of God in relationship that mission flows (cf. Wright 2004:133) and so mission is grounded in the Trinity. The missio Dei although grounded in the Trinity never escapes an anthropological grounding of missions (cf. Flett 2010:77). The identification of oikovoui $\alpha$ with the missio Dei then does not create a dialectical disjunction of the divine and human because the term oikovoui $\alpha$ is used for both the divine and human in Ephesians. For this reason the missio Dei which has been identified with the self-revelation of the Trinity in Ephesians can be concretely identifiable with the task oíкоvouí $\alpha^{8}$.

\subsection{The use of oikovopía in Luke and Ephesians}

The administration of the universe or cosmos by God for Paul is a oikovouía, a management and ordering of the cosmos, which in Luke's thought and sense of the concept is in a narrower sense the management of the resources that have been entrusted by God for the well-being of society". "Only in two New Testament

8 Mission is an action of God that flows out of his love and grace (Joh 3:16), his eternal plan of redemption (oikovouía; Eph 1:10) carried out by the Trinity. The being of God and his actions are inseparably linked (cf. Volf 2006:108).

9 In the working out of the plan of God the concept of oikovouía, has the meaning of the stewardship of resources in the book of Luke. 
parables is oikovouos used in the sense of stewardship of possessions in a more secular sense" (Lk 12:42; 16:1-4) (Foster 1995:15). The social and relational dimension is expressed by the task of oikovouí $\alpha$ in Luke in terms of the love and justice of the kingdom, marginalization, healing, economic transformation and the demonstration of the authority and power of Jesus over evil takes place in the relation between the present and future age. In Luke there is an eschatological dualism between the present, world/age and future ages (cf. Ireland 1992:71). The casting out of demons in Luke demonstrates that the kingdom of God is present. "Luke wants the rich and respected to be reconciled to the message and way of life of Jesus in keeping with the social message of Jesus" (Schottroff \& Stegman 1986:91; Bosch 1991:102).

\subsubsection{The development of oikovouía from Luke to Paul and the missio Dei}

The term oikovouí $\alpha$ is used in a different context by Luke than Paul in terms of the sphere of application of the term, which in Luke focuses on the temporary nature of the task of oikovouí $\alpha$ as a delegated responsibility and is applied by Paul to his own and the proclamation of others (cf. 1 Co 4:1; 1 Pet 4:10; Tit 1:7) (cf. Foster 1995:15). A logical extension and progression occurs from oikos in Luke to polis and ultimately to the kosmos or universe in Paul (Eph 1:22-23; Col 1:15-23) (cf. Reumann 1992:15). The extension of the sphere of influence from the oikos in Luke to the polis and to the kosmos or universe in Paul is discernable through the employment of the concept of oikovouía (Lk 12:39; 16:1-9; Eph 1:22-23; Col 1:15-23). The progression is from the limited sphere of influence of the oikos to the wider sphere of the polis till the widest possible sphere of influence, the kosmos. For Luke oikovouí $\alpha$ is a task carried out by the oikovouos who is a person to whom the task has been committed of the management of the oikos for the wellbeing of the household and in Paul it is for the harmony of the kosmos. Luke uses the concept of oikovoui $\alpha$ in the sense of the strategic order and arrangement of history in Acts (cf. Reumann 1992:87) and Paul for "the plan of salvation," or "administration of salvation" (cf. Foster 1995:15). Luke arranges his material in both his Gospel and Acts around the idea of three eras, the age of Israel, the time of Jesus and the age of the church (cf. Reumann 1992:87) whereas Paul uses two ages, the present and future age (Eph 1:13 \&14;1:21) or the past and present age (Eph 2:3 \& 4-7; 11-12 \& 13). In the epistle to the Ephesians oikovouí $\alpha$ is the central concept around which Paul develops his letter. The plan of God is depicted against a cosmic background and the climax of the reign of Christ over the cosmos (Eph 1:10; 1:20-23). The phrase "the fullness of time" (Eph 1:10) is used as a type of 'preview' to the confessional formula in Ephesians 1:15-23 (cf. Floor 2011:471472). The concept of missio Dei which can be applied to Paul's use of oikovouía 
distinguishes it from Luke's. The activity of oikovoui $\alpha$ is the activity of the human

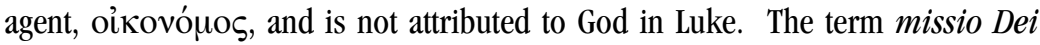
indicates that "mission is the work that belongs to God" (Vicedom 1965:5). The application of the missio Dei to the divine activity of oikovouí $\alpha$ in Ephesians 1:10 reflects the originally intended meaning of the term. The significance of missio Dei is that it indicates that mission is not "the mission of the church, even less of our mission" (Vicedom 1965:5) and so it is appropriately applied to the activity of God, oikovoui $\alpha$ (Eph 1:10). The term missio Dei is associated with oikovoui $\alpha$ as the activity of the Church as it participates in God's plans and purpose through obedience to a word of the Lord, commitment to the ingathering of the congregation, and participation in the establishing of the Lordship of Christ over the whole redeemed creation (cf. Eph 1:10; 3:9-10). In the application of the term by the IMC and WCC $^{10}$ "the meaning of mission and the theological understanding of missio Dei underwent a radical shift very soon after this initial expression-a shift that brought about the opposite of what was originally intended" (Vicedom 1965:157) ${ }^{11}$. The linking of the missio Dei with oikovouía indicates that the term missio Dei indicates the eternal redemptive plan of $\operatorname{God}^{12}$.

\section{The unification of the earthly and heavenly spheres}

The created order in Ephesians is conceptualized in terms of two spheres, the earthly sphere and the heavenly (Eph 1:3, 10, 20; 2:6; 3:10; 4:9-10; 6:12). Mission for Paul takes place in the context of the relation of the earthly, the visible, and heavenly, the invisible, spheres. The soteriology of Ephesians is expressed in a contrast of the earthly and heavenly spheres (Eph 2:6). Paul's use of oikovouí $\alpha$ in Ephesians is set within a cosmological context. He contextualizes the concept of oikovouí $\alpha$ in a cosmological framework in Ephesians to demonstrate the cosmic significance of oikovoui $\alpha$ and thus mission. God's reign is depicted as cosmic

${ }_{10}$ WCC $=$ World Council of Churches.

${ }^{11}$ It is after the Ecumenical World Conference in Willington (1952) that George F. Vicedom used the term missio Dei in his book with the same title (1958), after which writers commonly began to use this term (cf. Bosch 1991:390). Since then there has been no consensus as to its use and meaning. Richebächer (2003:465) indicates that certain researchers use the term to describe the Christocentric character of mission (cf. Hirsch 2006:83-110). The shift that has taken place is that the term has been used to describe a deity who reveals himself in various religions (cf. Sundermeier 2003:560). "Missio Dei is basic to a theological understanding of mission and dysfunctional to the point of being rejected ...' (cf. Flett 2010:6; Keller 2012:256). The shift that has taken place is that it has shifted from an ecclesiocentric to a theocentric approach (cf. Breed 2014:2).

12 Wright (2008:531-532) identifies missio Dei with "the purposeful, sovereign, intentionality of God", the redemptive plan of God. He defines the missio Dei in the NT specifically as, "the plan, purpose and mission of God for the whole creation, that it will be reconciled to God through Christ by the cross" (Col 1:20). The author of Ephesians sums the plan up by the use of $\quad \mu$ (Eph 1:10). 
(Eph 1:20-23) and the proclamation of the gospel has cosmological ramifications (Eph 1:10). The beginning of the process of restoration and renewal is indicated and the end of the process is anticipated in Ephesians 1:9-10 13 by the noun $\tau$ o $\tilde{v}$

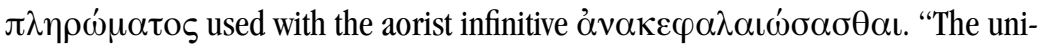
versal ramification or summing up of all things in the fullness of times need not be taken as an exclusively future event" (Grizzle 2013:38). It is the eschatological end point and goal of God's purpose for creation that is expressed by oikovoui $\alpha$ in Ephesians 1:10 (cf. Grizzle 2013:38). In Ephesians 1:10 the aorist infinitive of $\alpha v \alpha \kappa \varepsilon \varphi \alpha \lambda \alpha \iota \omega \sigma \alpha \sigma \theta \alpha \iota$ indicates the continual process of "all things" being brought in unity with Christ (Eph 1:10). The aorist infinitive points to the past and the continuation of the purpose since the infinitive signifies purpose, the goal to be achieved (cf. 0'Brien 1999:114). The aorist used together with the infinitive has in view the progression and future full realization of what has already been fulfilled in the Christ event ${ }^{14}$. Schnackenburg (1991:61) has an over realized eschatology when he writes, "One thing is clear from 1:10: the unification of the universe in Christ, the restoration of the divine rule of the universe has already taken place"15. The oikovouí $\alpha$ task of Christ and his mission from heaven will continue until the missio Dei is fully realized in creation and through the church (Eph 1:23). In Ephesians 1:20-23 the reign of God as head over all powers and principalities is indicated as having been realized in principle by the noun $\tau$ ò $\pi \lambda \eta \dot{\eta} \rho \omega \mu \alpha$ used with aorist $\dot{v} \pi \dot{\varepsilon} \tau \alpha \xi \varepsilon v$ to indicate a completed action ${ }^{16}$. The headship of Christ (Eph 1:20-23) is to be read as distinct from the unification process of the summing up of all things in the cosmos (Eph 1:10) yet with the same result, the headship of Christ over all things. In terms of 1:10 it can be represented in concentric circles that has begun with the confession of the headship of Christ and the task of oikovouía given to Christ and is moving towards the center, the fully realized headship of Christ over the restored and renewed creation which will revealed in the fullness of time (Eph 1:20-23). The headship of Christ is a present reality but the unification of the cosmos is a process which will culminate in the full revelation of the headship of Christ over the cosmos. So all of creation is progressively moving towards the full revelation of Christ as head ${ }^{17}$.

\footnotetext{
${ }^{13}$ In Ephesians 1:9-10 the apocalyptic term, "the fullness of the times" is "yet still awaited "day of redemption" (4:30) (Turner 1995:142).

14 "While the fullness of the times" may commence with the Christ event (so e.g. M. Barth, Schnackenburg and Lincoln) the author can hardly be suspected of believing the has been completed" (Turner 1995:142).

15 "The re-unification is not yet complete; rather in the present age, the church must grow towards it" (Turner 1995:143).

${ }^{16}$ An eschatological tension exists between the present and aorist eschatology.

${ }_{17}$ Ephesians 1:10 is concerned with the process whereas the focus of 1:20-23 is the end result.
} 


\subsection{The result of the unification of the spheres and the missio Dei}

The result of the unification of the earthly and heavenly spheres is spiritual blessings. In Ephesians the blessing of the restored humanity is expressed as "spiritual blessings in Christ" located "in the heavenly sphere" (Eph 1:3). The visible and invisible spheres were in relational disunity as a result of the rebellion of mankind that brought evil and sin into both these spheres (Gen 3). It is through the oikovouí $\alpha$ work of Christ that the unity is being restored in relation to him, in Christ. The oikovoui $\alpha$ has cosmological ramifications in that the person and work

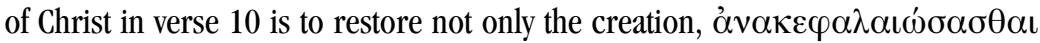

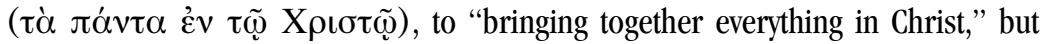
the original blessing of God through the unification of both these spheres. It is the

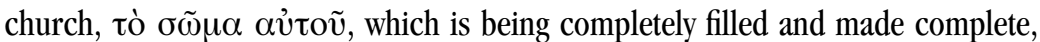
$\pi \lambda \eta \rho о v \mu \varepsilon \dot{\varepsilon} v v$ and the place where the process of unification is taking place ${ }^{18}$. The complete filling of the church has a missional dimension because it is in and through the church being perfectly under the direction of its head that a visible testimony of the process of unification culminating in the headship of Christ (Eph 1:20-23) is given. Christ will fill everything, the earthly and heavenly realms, with his glory at the completion of the missio Dei.

\subsection{The relation of Ephesians 1:9-10 and 1:20-23 and the missio Dei}

The term oikovouí $\alpha$ used in the cosmological context of the unification of the heavenly and earthly spheres indicates that creation is being brought together and unified in Christ (1:10). The process of unification in Ephesians 1:10 is distinct from the actualized headship of Christ over the cosmos in 1:20-23. Ephesians 1:10 and Ephesians 1:20-23 are from two separate and unique vantage points. The unique salvation-historical revelation of each of these two texts is to be maintained ${ }^{19}$. It is by means of a missional reading or hermeneutic and what can be called missional exegesis that the relation between 1:9-10 and 1:20-23 becomes evident. The headship of Christ over the cosmic powers and principalities is confessed by the church but it is the missio Dei to unify of all of creation (Eph 1:10) culminating in the revelation of the headship of Christ over all of creation (Eph 1:20-23).

The relation of Ephesians 1:9-10 and 1:20-23 is thus based on the reunification of the cosmos in Christ. In Ephesians 1:20-23 what comes to fore is that the beginning of the reunification is taking place in the church. The church is presented as the eschatological oneness of the body of Christ (cf. Gal 3:28; $1 \mathrm{Co} 12: 13$; $\mathrm{Col} 3: 11$ ) and presents

${ }^{18}$ The least problematic view is that it is Christ who, as fullness, fills the church and as it head directs it (cf. Grizzle 2013:49).

19 Schnackenburg (1991:58-61) reads Ephesians 1:10 from the perspective of Ephesians 1:20-23. 
an exalted vision of the church and its calling: "to be the place and people whose supernatural, eschatological unity embodies and displays in the present the unification of the whole cosmos is Christ which is yet to come (cf. also Eph 3:6; 8-10)" (Barton 2004:248). The oikovoui $\alpha$ of God is the execution of the salvation historical plan of God in which the church has a role and it is therefore appropriate that it be identified with the missio Dei. The missional ecclesiology of Ephesians in 1:20-23 is not about a world dominating church but a world-wide mission. The missional ecclesiology of Ephesians present a world-serving missiology as opposed to "the victory of a triumphant ecclesiology" (Senior \& Stuhlmueller 1983:191).

\section{The submission of the spiritual beings to Christ}

The process of unification of the earthly and heavenly spheres is a unification of the spiritual powers and principalities, the good and evil spiritual beings, under Christ. The verb óv $\alpha \kappa \varepsilon \varphi \alpha \lambda \alpha$ เó $\omega$, "to bring back into unity" derives from the noun $\kappa \varepsilon \varphi \alpha \lambda \alpha$ เóv ("main point", "summary") rather than $\kappa \varepsilon \varphi \alpha \lambda \eta$ ("head") and the meaning of the verb $\alpha v \alpha \kappa \varepsilon \varphi \alpha \lambda \alpha \iota \omega \sigma \alpha \sigma \theta \alpha$ "to bring to a summary" instead of "to bring under one head" (Turner 1995:139). The importance of this is that the unification motif of Ephesians 1:10 is distinct from the headship motif of Ephesians 1:20-23. The unification motif "is applied to Christ's eschatological relationship to a multitude of entities (including personal beings) scattered throughout the universe" (Turner 1995:139). The goal of oเкоvouı $\alpha$ is to once more reconcile "all things, in heaven and on earth". God's eschatological intent is in one accord with the divine good will set forth in Christ - a reference aimed at his ministry of reconciliation (cf. Turner 1995:140). The bringing of all of creation under Christ as head over the cosmos means that all of creation is continually being drawn into an intimate and meaningful relationship with Christ which has a rippling effect and will result in all of creation being drawn into a more intimate relationship with $\mathrm{Christ}^{20}$. Jesus Christ as the source of all life is the pivotal point of all of creation, the revelation centre and the goal of oเкоvо $\mu \mathrm{\alpha}$ and the missio Dei. The harmonisation of creation includes all things in the heavenly spheres, the spiritual powers in opposition to the rule of Christ and all elements in the heavenly sphere (cf. Calvin 1972:63). It is in relation to that harmony is restored.

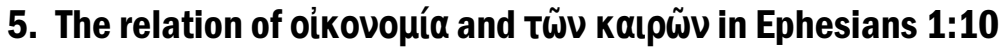

The conceptualization of oikovoui $\alpha$ in Ephesians is grounded in missions ${ }^{21}$. In Ephesians 1:10 oikovoui $\alpha$ has the meaning of the ongoing execution of the plan of

${ }^{20}$ The universe "will continue to be subjugated ever to a greater degree, in the earthly historical space" (Schnackenburg 1991:61) indicating growth in the process of subjugation. 
God by Christ. It the continuing living, bodily, history-shaping movement of God towards the world in Christ (Eph 1:10) and through the church to the world (Eph 1:2023) that is expressed by the use of oikovouía. It is about the renewal of life in which the fullness God planned before creation is experienced as unfolding in the context of the present corruption (cf. Eph 2:10). The fullness of time is the perfect timeframe

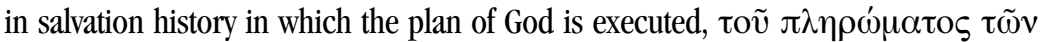

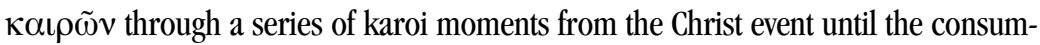
mation. "What is expected in the end is already in progress" (Grizzle 2013:38). The word kairos is used for the time of God's active involvement in the present time to bring about the consummation. The plural is used to speak about the kairoi periods as series of consecutive and significant moments in salvation history (cf. Floor 2011:471). The fulfilment of the time means that the bringing together of heaven and earth stands in a continuum with Jesus' baptism, transfiguration, crucifixion, incarnation, the mission of the resurrected Lord, and the mission of the church culminating in the exaltation of Christ in the fullness of the times. The church is involved in what God in Christ will do in the future (cf. Floor 2011:469).

\subsection{Harmonious ethnic relations in the church part of the missio Dei}

The oikovoui $\alpha$ of God's plan is executed in that it is through Christ, $\dot{\varepsilon} v \tau \tilde{\omega}$ X

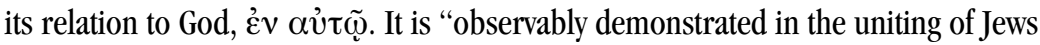
and Gentiles in Christ" (Grizzle 2013:38). It is part of the missio Dei in that the restoration of the unity of Jew and Gentile is a central part of the restoration of harmony in creation (Eph 1:11). The restoration of harmonious ethnic relations in the church is a prefiguration of the restoration of all of the relations in creation as part of the execution of God's plan. The oikovoui $\alpha$ work of Christ is holistic, cultural and savific. The separation of peoples into ethnic groups and nations that occurred at Babel is reversed in the new covenant missional community, the church. The unity of Jew and Gentile as a witness to the presence of the power of the Spirit that was poured out upon the church at Pentecost (Acts 1:8) is linked to the gospel and Spirit in Ephesians. The Spirit's function in the process of unification cannot easily be overlooked. The execution of the plan of God is missional in its very essence: "everything brought together under Christ" undoubtedly means first of all, all believers from all nations brought together under Christ. It is set against the context of the "divinely superintended ingathering of the nations of OT expectation" (cf. Bowers 1992:172; cf. O'Brien 1993:54). The content of his plan is not said here, but in the light of Ephesians 2:11-13 and 3:4-6 the plan proves to be that all peoples/ nations should share in the covenantal promises of God that have become true in Christ. A missional correlation exists between Luke and Paul in terms of the 
gathering in of the nations as the same OT texts is used by Luke and Paul for the inclusion of the Gentiles.

\subsection{The role of Christ in the renewal of the purpose of creation}

The oikovouí $\alpha$ of God gives a renewed purpose and direction to creation, it fulfills its created function of pleasing God (Eph 1:9, 12). The preposition and the accusative oikovoui $\alpha$ in Ephesians 1:10 indicate the duration of time, "to (carry out) the task until the times will have reached their fulfilment". It is a task that will be performed by Christ until the end of the age is consummated. Taking this plan of God into account - and considering the focus that the entire Ephesians letter has on Christ - the most central place is taken by the work of Jesus Christ. The phrase in Christ ( $\dot{\varepsilon} \vee \tilde{\omega})$ occurs 4 times in Ephesians 1:3-14. It is especially in Ephesians 1:7-12 that God's work in Christ in relation to the believer is expounded through the dative phrases. The dative phrase

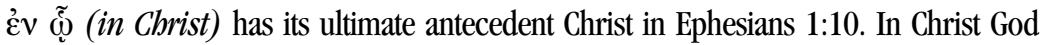
planned to bring everything together in him and central in the summing up of everything

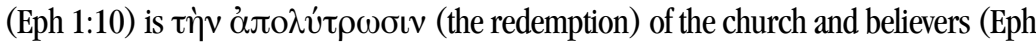
1:7). God's plan is to gather everything into a living unity with him. He takes the initiative to reveal his purpose and plan for the church (Eph 1:23).

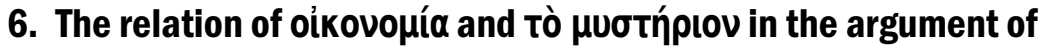 Ephesians 1:7-10}

The argument of Ephesians 1:7-10 is as follows:

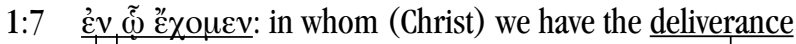

Verb 1

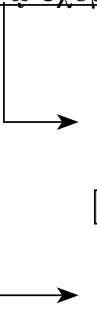

through his death,

the forgiveness of sins,

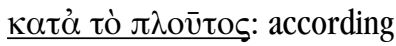

to the greatness of his grace

$1: 8$

which He caused to be in abundance in us

PTC 1

$1: 9$

in all wisdom and ability to understand

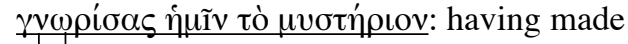

known to us the secret of His plan

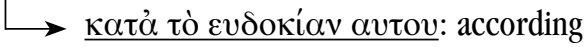

to his desire which he planned

beforehand in Him

$1: 10$

cic oíkovouiav: so as to be (the)

plan of the fullness of the times to

Purpose 1

bring together everything in Christ the

things in heaven and the things on earth

in him. 
The oikovoui $\alpha$ of God in Ephesians 1:10 must be read in the light of the overarch-

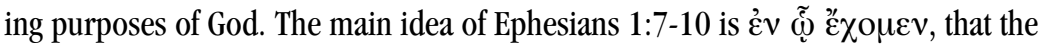
task of oikovoui $\alpha$ is the mediation of deliverance and redemption through the death of Christ (Eph 1:7). In this way the task of oikovoui $\alpha$ and the missio Dei

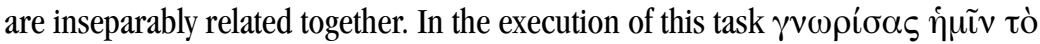

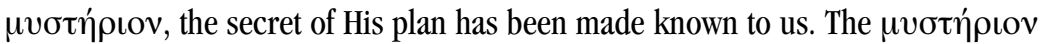
is made known to the church and the believers individually as part of the execution of the oikovouí $\alpha$ of God. An important missional perspective in Ephesians 1:9 that has been made known to the church is the mystery of the will of God. This

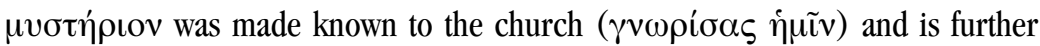

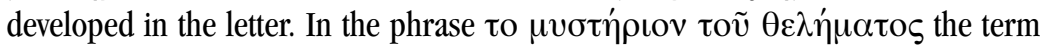
$\theta \dot{\varepsilon} \lambda \eta \mu \alpha$ has in view God's eternal decision as the starting point for the oikovouí $\alpha$ of God. God the Father was pleased in the plan made beforehand in Jesus Christ, to reveal his plan in Jesus Christ in the kairos moment in history. And the church has the responsibility to continue to reveal the fulfillment of the plan in the Christ event and so become involved in the "fulfilment of the fullness of the times".

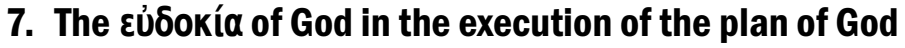

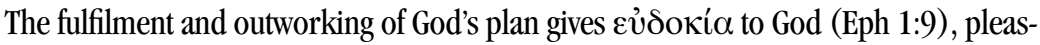
ure and self-satisfaction to him. It is the process and not simply the end result that pleases and continues to please Him "... until the times will have reached their fulfilment". "When all the times and seasons which the Father has fixed by His own authority have ran their course, God's age-long purpose which He planned in Christ will attain its full fruition" (Bruce 1977:33). It is specifically the pleasure of the full realization of his plans and purpose (1:9). The redemption of the church is part of the $\varepsilon \dot{v} \delta$ oкi $\alpha$ (Eph 1:9), it is the redemption of the church that gives God pleasure. God is favourably ( $\dot{\varepsilon} \chi \alpha \rho i \tau \omega \sigma \varepsilon v)$ disposed to the church in the execution of his plan

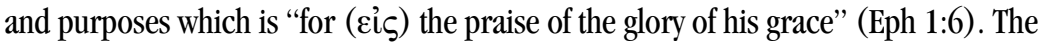

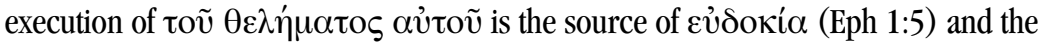
outworking of the oikovoui $\alpha$ of Christ is the fulfilment of the plan and purpose that God had planned before in Him (Eph 1:5). God himself fulfils his plans and purposes through the oikovouía work of Christ. Wright (2006:531-535) makes a valuable contribution towards a definition of the missio Dei in terms of oikovouía when he says that it should be understood as the "purposeful, sovereign intentionality of God".

\section{The ßouגń (purpose) $\theta \varepsilon \dot{\lambda} \eta \mu \alpha$ (will) of God}

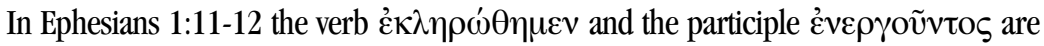

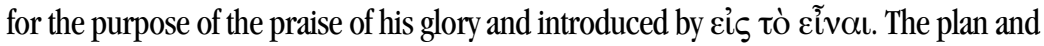
purposes of God is revealed in the calling and appointment of individuals in the plan and 
purpose of God. The task of oikovouí $\alpha$ operates according to the plan and purpose of God, the $\beta o v \lambda \eta$ (purpose) and $\theta \dot{\varepsilon} \lambda \eta \mu \alpha$ (will). The peculiarity of Ephesians 1:11 lies in the linking of the whole oikovouí $\alpha$ of God with His $\beta$ ov $\lambda \dot{\eta}$. The terms $\beta$ ov $\lambda \dot{\eta}$ (purpose) $\theta \dot{\varepsilon} \lambda \eta \mu \alpha$ (will) are to be read in the light of the overarching purpose of God as it has been narrated in the Old Testament (cf. Green 1997:22-49). The term ßov $\lambda \eta$ is "God's overarching theological plot-God's unfolding plan of salvation" (Spencer 2005:112). The term $\theta \dot{\varepsilon} \lambda \eta \mu \alpha$ reveals the universal and salfivic will of God, the "decisive resolve" in the execution of the divine plan (cf. O'Brien 1999:117). The concept of oikovouí in Ephesians is also to be seen in the context of the whole biblical story as Christ serves the missional purpose of God. The mission of Jesus in the Gospels is part of the execution of the missio Dei and oikovoui $\alpha$ in Ephesians 1:10 stand in a continuum with Jesus earthly ministry. For this reason it is part of the salvation-historical framework of the ongoing story of God's redemptive work and stands in a continuum with Jesus' mission in Luke and the gospels (cf. Green 1997:125). The linking of the oikovouí of God with His $\beta$ ov $\lambda \eta^{\prime}$ can be understood to mean that Jesus Christ will fulfil the will of God, the task, "to bring everything together" ( $\alpha v \alpha \kappa \varepsilon \varphi \alpha \lambda \alpha u \omega \sigma \alpha \sigma \theta \alpha)$ in himself. The implication is that God's purpose and mission will always be accomplished (cf. Eph 1:11). In the execution of the plan and purposes of God, Jesus Christ

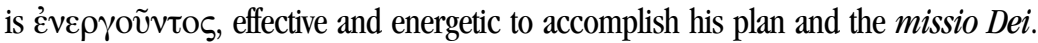

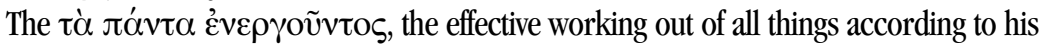
purposes and will, is "for the praise of the glory of Him" (Eph 1:12). The phrase $\dot{\varepsilon} v \tilde{\varphi}$

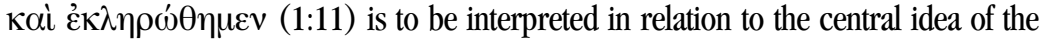
execution of the oikovouí $\alpha$ of God in Christ (1:10).

\section{Election and purpose}

\section{The argument of Ephesians 1:11-12 is as follows:}

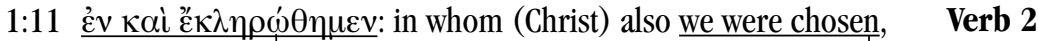

$$
\begin{aligned}
& \text { decided upon beforehand, }
\end{aligned}
$$

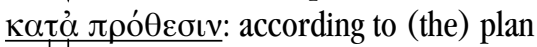

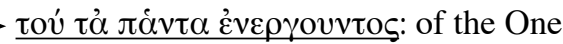

$$
\begin{aligned}
& \text { bringing everything about }
\end{aligned}
$$

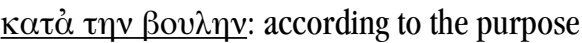

$$
\begin{aligned}
& \text { of His will }
\end{aligned}
$$

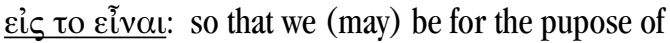

Purpose 2

(the) praise of His glory, the ones having been first

to hope in Christ.

The term $\mathfrak{\varepsilon}^{\prime} \xi \varepsilon \lambda \varepsilon^{\prime} \xi \alpha \tau$ in Ephesians 1:4 refers to God's gracious initiative in eternity in saving those who would believe in Christ. God's freedom is revealed in that it is 
according to his will and purpose that He takes the initiative. Missions is the means by which those outside of the church who have been elected according to God's freely-determined action receive the message by which they are saved. The author's intention in Ephesians 1:3-14 is not simply the development of a personal and individualistic soteriology but the relation of election to the intended climatic goal: "to the praise of his glory" (Eph 1:12, 14). It is for the purpose of the accomplishment of God's plan and purpose and for those who are elected to participate in the missio Dei that the author indicates that Jew and Gentile are redeemed. The verb ${ }_{\varepsilon} \xi \xi \lambda \dot{\varepsilon} \xi \alpha \tau$ is in the middle voice. "The middle voice when used in the NT stresses "the relation of the person chosen to the special purpose of him who chooses" (Westcott 1978:8). The purpose of election in Ephesians 1:4 is for the purpose of service. The term often alludes to selection for a position of service, and is used of Jesus' twelve disciples (Lk 6:13; cf. Mk 3:13-14). It is instrumental in the fulfilment of the missio Dei.

\section{Calling and the oikovouía of God}

10.1 The calling of Jew and Gentile to participate in the missio Dei

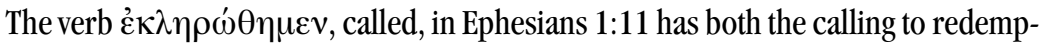
tion and missions as its goal because of the minus Dei (called) and the missio Dei belong together. The plan and purposes of God are about the redemption of the church for the purpose of participating in the missio Dei, and so the church and missions are linked. The term $\dot{\varepsilon} \kappa \lambda \eta о \rho \omega$ indicates that the believer has a calling in the plan and purpose of God. The basic meaning of $\kappa \lambda \tilde{\eta} \rho \varsigma_{\zeta}$ was used to indicate God's favourable disposition towards Israel in the OT in past dispensations and his favourable disposition towards the church in the present dispensation. It has been correctly suggested that the Jew-Gentile relation to the mystery has not sufficiently been taken into account in Ephesians 1 (cf. O'Brien 1999:117). Paul acknowledges the various ethnicities in the church and that there is in the oikovouí of God an order of revelation, firstly to the Jew then to the Gentile. The Jews are the ones having been first to hope in Christ. He acknowledges the place of the Jew in God's salvation historical plan and purpose as the first people of God and recipients of revelation prior to be inclusion of the Gentiles. The oikovouí of God (Eph 1:10) is related to God's plan which is for both Jew and Gentile.

\subsection{The inclusion of the Gentiles in the missio Dei}

In Ephesians 1:3-13 $\eta \mu \tilde{\alpha} \varsigma$ (us) in the plural is used for all the Christians, Jew and Gentile, and $\dot{\eta} \mu \varepsilon \tilde{\varsigma} \varsigma$ does not occur but the 1st person plural of the verb

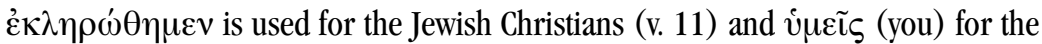
Gentiles (Eph 1:13). The "we" are those "who first trusted in Christ" (Eph 1:12). 
He recognizes that the Jewish ethnic group was the first to have received the message of salvation and reinforces their unique place within the divine plan of God. The Jewish Christians are identified as those who hoped in a prior manner, beforehand or prior to the Gentiles by the use of the verb $\pi \rho 0 \eta \lambda \pi \iota \kappa o$ o $\alpha \varsigma$ (Eph 1:12).

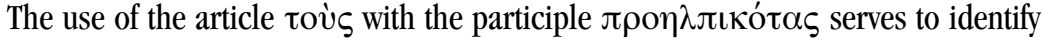
the "ones" in their continuing state of hope. The use of the plural "we also" in v. 11 and "you also" in v. 13 indicates Paul's order of address, he addresses the Jewish Christians first and identifies himself with this ethnic group as distinguished from the Gentile Christians (cf. O'Brien 1999:115). The kai (also) at the beginning of v. 11 and 13 indicates a change of subject from the Jewish to the Gentile Christians. "It is being asserted that in the wider purposes of God's saving plan, it was those of Jewish origin, the more immediate heirs of "the covenants of promise", (0'Brien 1999:116) who are to the praise of his glory. The Jews were the first to be included in Christ.

In Ephesians 1:14 $\eta \mu \tilde{\omega} v$ (us) is used with $\kappa \lambda \eta \rho o v o \mu i \alpha \varsigma$ to indicate emphatically the movement from the exclusive Jewish inheritance (v.11) to the inclusive inheritance of Jew and Gentile mutual inheritance. The "us" in the Eulogy means all Christians chosen "in Christ" (cf. Schnackenburg 1991:64) with the exception of the use $\eta \mu \tilde{\alpha} \varsigma$ (us) in v.12, which is used differently. ${ }^{22}$ The inclusion of the Jews were

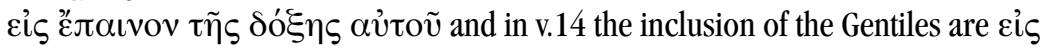

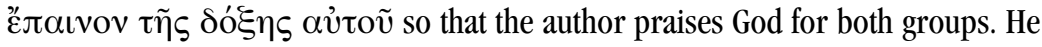
spontaneously breaks out in praise after considering the inclusion of each group. The execution of the plan of God, oikovoui $\alpha$, is progressive, first the Jews were included in Christ and then the Gentile nations in the working out of the plan of God.

\section{The inclusion of the Gentiles through the gospel}

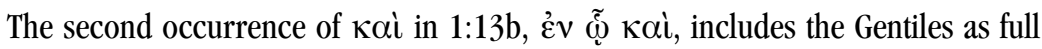
recipients of promise of the Holy Spirit. The inclusion of the Gentiles in Ephesians 1:13 is presented as an equal and full participation of the Gentiles in the promised plan of salvation and the promise of the Holy Spirit (Eph 1:13). The language of "through the gospel" (Eph 1:13) has been identified as language of evangelization (cf. Schnackenburg 1991:65). "The author of Ephesians is concerned solely with the fruitful reception of the salvation-brining gospel (cf. 3:6) and with the deeper understanding of the "mystery of the gospel" (cf. 6:10) (Schnackenburg 1991:65). The gospel is the instrument through which the nations are incorporated into the new covenant community and the plan of God for the inclusion of the nation's to

${ }^{22}$ Contra the use of $\mu$ Schnackenburg (1991:64) writes "there is no indication of a different interpretation in v.12". 
be fulfilled. "The Pauline connection between hearing the gospel, believing, and receiving the Spirit is made, and these are important elements of conversion-initiation" (0'Brien 1999:120). The emphatic personal pronoun "your" reminds the readers of their conversion, and focus attention on the transforming power of the gospel message. Election in Ephesians is according to $\theta \dot{\varepsilon} \lambda \eta \mu \alpha$, a "decisive resolve" by God and personal identification of the converted with Jesus Christ which is expressed by in Christ. The irreversible order is that it is the person who is in Christ who has been elected according to the will of God. The author corrects the ethnic centrism of Judaism that defined election in terms of belonging to a Jewish ethnic identity and made conversion a pre-requisite for both Jew and Gentile (Eph 2:1-3). The bringing together of all things in Ephesians 1:10 is by means of the proclamation of the gospel, the message of repentance and the promise of the Gospel to all people (cf. Eph 3:6). It is the brining together of all ethnic groups and the nations that is part of the oikovoui $\alpha$ of God in the time until consummation. The inclusion of the Gentiles implies their inclusion in the missio Dei.

The Jew and Gentile are equally the $\kappa \lambda \eta \rho o v o \mu i \alpha s$, the property of God the Father who He has set them free and continues to set them free. It climaxes in a final purpose clause of the thought unit Ephesians 1:7-14, "for the praise of the glory of Him" (Eph 1:14). The way in which God administers his plan (oikovouí $\alpha$ ) is first of all by having made known ( $\gamma v \omega \rho i ́ \sigma \alpha \varsigma$ ) to "us" (i.e. the already existing Jewish believers) his long waited and unknown plan ( $\mu v \sigma \tau \eta \dot{\rho} \rho\llcorner o v)$ for the restoration of all of creation.

\section{The sealing of the Holy Spirit for missions}

In Acts 1:8 the Holy Spirit is poured out on diaspora Jews who are converted, enabled and empowered as Jewish Christians to spread the gospel from Jerusalem, to all Judea, Samaria and the ends of the earth. The promise of the Holy Spirit is intended for all ethnic groups and nations and there is a certain order in the execution of God's plans so that in Luke-Acts although the promise of the Spirit to the Gentiles is given in Luke 24:47-49 it is in Acts 10 that the Holy Spirit is for the first time symbolically poured out upon the Gentiles and the way opened for the gospel to spread to the Gentile nations and they are drawn into active participation in the mission of God's people and the mission of the Servant. In Ephesians 1:13 Paul mentions that during the preaching of the gospel an experience of trust in the proclaimed message takes place through the work of the Holy Spirit (cf. Roberts 2011:498). The experience can be described as a conviction of the conversion of God (cf. Roberts 2011:498). The sealing by the promised Holy Spirit is a profound experience upon the hearing of the proclaimed word of God. The preaching of the word is the means through which the ethnic groups and nations are brought back into unity. The "message of truth" reveals the truth of God, 
and his saving purposes and humankind's place within them (cf. O'Brien 1999:119). The language of "the message of truth, the gospel of your salvation" "is part and parcel of the early Christian mission terminology" (0'Brien 1999:118). It is particularly related to oikovoui $\alpha$ (Eph 1:10) and reminds the readers of their conversion and draws attention to what this powerful message has accomplished for them (cf. Ro 1:16). The sealing by the Holy Spirit is related to the oikovoui $\alpha$ of God and indicates that God retains the missionary enterprise in His own hands and does not surrender it to any human authority.

\section{The role of the Church in the oikovouí $\alpha$ of God}

The church has a role in the gigantic, cosmic plan of God (cf. Floor 2011:476). The role of the church is to bringing the ethnic groups and nations back into unity. The election of Israel as God's people was for the nations (cf. Wright 2004:135). Israel did not exist for itself but for God and his glory among the nations. The mission of Israel has become the mission of the Church and so the church does not exist for itself but for God and the revelation of his glory among the nations. Paul writes in Ephesians 1:11 that the believers are chosen and appointed in him in the meaning of $\kappa \lambda \eta \rho o ́ \omega$ ('to be chosen by lot,' not occurring in the NT) with the implication of elected for the task of calling the nations back into relationship with Christ. It is more than a soteriological term, it is also a missional term and indicates a role and task of the converted Jew and Gentile in the restoration of harmony in creation. The church participates in God's gracious purpose to unite everything in Christ. The Church is the instrument of Christ to bring together all things and it does so through the preaching of the gospel to those inside and outside of the community.

\section{Conclusion}

The use of a missional hermeneutic and reading of Ephesians provides new insights and understanding of the use of oikovouí $\alpha$ in Ephesians 1:3-14. In the epistle to the Ephesians it makes possible new insights into the use of oikovouía, a central concept around which Paul develops his letter. The reflection on the use of oikovouí in Ephesians in past research has identified the concept with the cosmological context of the letter. The application of a missional hermeneutic has provided a reason that the concept of oikovouí $\alpha$ has been contextualized in a cosmological framework in Ephesians, to demonstrate the cosmic significance of God's mission, the missio Dei. It has been demonstrated in this article that an association exists between oikovouí $\alpha$ as the activity of the God in Ephesians 1:10 and the church which is called to participate in God's plan and purpose which is already implied in Ephesians 1. The relationship of the missio Dei and the church is, however, not fully developed until Ephesians 3. The association that the author 
of Ephesians makes between oikovouí $\alpha$ and the missio Dei distinguishes it from Luke's understanding of oikovouí $\alpha$ as the activity of the oikovouos (steward). It has been demonstrated that oikovouí $\alpha$ is used in Ephesians 1:10 as a missional term and this will require further support through an investigation of the use of the term in the rest of the letter to the Ephesians. The results can then be compared with the use of the term in the Pauline corpus to arrive at a definitive conclusion as to whether oikovouí $\alpha$ is to be read as a missional term in all of its occurrences in the Pauline Epistles.

\section{References}

Barton, S.C. 2004. The unity of humankind as a theme in biblical theology. (In Bartholomew, C, Healey, M, Moller, K, Parry, R, eds. Out of Egypt: biblical theology and biblical interpretation. Grand Rapids: Zondervan: 102-143.

Bowers, W.P. 1992. Paul's missionary calling within the purposes of God, in The fullness of time: biblical studies in honour of Archbishop Donald Robinson, edited by Peterson, D. \& Pryor, J. Homebush West: Lancer: 131-148.

Bosch, D. 1991. Transforming mission: paradigm shifts in theology of mission. Maryknoll: Orbis Books.

Breed, G. 2014. 'n Kritiese blik op missio Dei in die lig van Efesiërs. In die Skriflig, 48(2): 1-10.

Bruce, F.F. 1976. The epistle to the Ephesians. Glasgow: Mohr Scott.

Calvin, J. 1972. Uitlegging op de zenddrieven van Paulus. Deel 2. Ed. By A.M. Donner. Goudriaan: De Groot.

Flett, J.G. 2010. The witness of God: the trinity, mission Dei, Karl Barth, and the nature of the Christian community. Grand Rapids: Michigan.

Floor, L. 2011. Een blauwdruk voor de toekomst. In die Skriflig, 45(2\&3), Jun/Sept:467-480.

Foster, R.A. 1995. Sign and substance of the Christian life taught in the New Testament. southwestern journal of theology, 37(2), Spring: 15-22.

Goheen, M. 2005. A critical examination of David Bosch's missional reading of Luke, in. Reading Luke: interpretation, reflection, formation, edited by Bartholomew, C.G, Green, J.B, Thiselton, A.C. Milton Keynes: Paternoster Press: 229-264.

Green, J.B. 1997. The gospel of Luke. NICNT. Grand Rapids: Eerdmans.

Grizzle, T. 2013. Ephesians: Pentecostal commentary series. Dorest: Deo Publishing.

Hirsch, A. 2006. The forgotten ways: Reactivating the missional church. Grand Rapids: Brazos Press.

Ireland, D.J. 1992. Stewardship and the Kingdom of God: an historical, exegetical, and contextual study of the parable of the unjust steward in Luke 16:1-13. Leiden: E.J. Brill.

Kaiser, W. 2008. The promise-plan of God: a biblical theology of the Old and New Testaments: Grand Rapids: Zondervan.

Keller, T. 2012. Center Church: Doing balanced, gospel-centered ministry in your city, Grand Rapids: Zondervan.

Lincoln, A.T. 1990. Ephesians: word biblical commentary. Dallas: Word Books. 
Louw, J. P., \& Nida, E. A. 1996. Greek-English lexicon of the New Testament: based on semantic domains. New York: United Bible Societies.

Newbigin, L. 1963. Trinitarian faith and today's mission. Richmond: John Knox Press.

0'Brien, P. T. 1991. The letter to the Ephesians. Grand Rapids: Eerdmans.

O'Brien, P.T. 1993. Gospel mission in the writing of Paul: an exegetical and theological analysis. Grand Rapids: Baker Books.

Roberts, J.H. 2011. Het Filemon vandag nog iets vir ons om te se? In die skriflig, 45(2\&3), Jun/Sept: 481-501.

Richebächer, W. 2003. 'Editorial', International Review of Mission 92(4): 463-467.

Schnackenburg, R. 1991. The epistle to the Ephesians: a commentary. Edinburg: T \& T Clark.

Schottroff, L, \& Stegman, W. 1986. Jesus and the hope of the poor. Maryknoll: Orbis Books.

Schulz, K.D. 2009. Mission from the cross: the Lutheran theology of mission. Saint Louis: Concordia Publishing House.

Senior, D. \& Stuhlmuller, C. 1983. The biblical foundations for missions. London: SCM Press.

Spencer, F.S. 2005. Preparing the way of the Lord, in Reading Luke: interpretation, reflection, formation, edited by Bartholomew, C, G, Green, J.B, Thiselton, A.C. Milton Keynes: Paternoster Press: 104-154.

Sundermeier, T. 2003. 'Missio Dei today: On the identity of Christian mission', International Review of Mission 92(4): 560-578.

Turner, M. 1995. Missions and meaning in terms of "unity" in Ephesians, in Missions and meaning: essays presented to Peter Cotterel, edited by Billington, A, Lane, T, \& Turner, M., Carlisle: Partnoster: 139-164.

Westcott, B.F. 1978. Saint Paul's epistle to the Ephesians. Minneapolis: Klock \& Klock.

Wright, C.J.H. 2004. Mission as a matrix for hermeneutics and biblical theology, in Out of Egypt: biblical theology and biblical interpretation, edited by Bartholomew, $\mathrm{C}$, Healey, M, Moller, K, Parry, R. Grand Rapids: Zondervan: 102-143.

Wright, C.J.H. 2008. The mission of God. Nottingham: Inter Varsity Press.

Wright, C.J.H. \& Lamb, J. 2009. Understanding and using the Bible. London: SPCK.

Van der Walt, T. 2009. Pentecost and consummation. Potchefstroom: Potchefstroom Theological Publications.

Van Egan, C. 1996. Mission on the way: issues in mission theology. Grand Rapids: Baker.

Vicedom, G.F. 1965. The mission of God: an introduction to a theology of mission. St. Louis: Concordia.

Volf, M. 2006. The Trinity is our social programme, in The doctrine of the trinity and the shape of social engagement, edited by Torrance. A.J \& Banner, M. New York: Clark: 105-124. 